\title{
Reading Poison: Science and Story in Nazi Children's Propaganda
}

\section{Daniel Feldman ${ }^{1}$ (D)}

Accepted: 19 May 2021 / Published online: 25 May 2021

(c) The Author(s), under exclusive licence to Springer Nature B.V. 2021

\begin{abstract}
Children's books of Nazi propaganda prove that a society can venerate science to the point of making biology the organizing principle of its educational system yet nevertheless produce children's literature shot through with fabrication and falsehood. Three children's books of Nazi propaganda that are frequently mentioned in accounts of anti-Semitism but seldom analyzed are discussed: Elvira Bauer's Trau keinem Fuchs auf grüner Heid und keinem Jud auf seinem Eid (1936), Ernst Hiemer's Der Giftpilz (1938), and Hiemer's Der Pudelmopsdackelpinscher (1940) illustrate the ways in which racist science and ideological narrative tautologically reinforce each other in an extreme version of how "narratives play a key role in communicating science" (Pauwels, 2019, p. 434) in children's nonfiction. These texts of lurid racism, all issued by the book publishing arm of Julius Streicher's virulently anti-Semitic newspaper Der Stürmer, offer a monitory case study of how bad science and toxic narrative can coalesce into a literary poison intended to indoctrinate young readers. This analysis of Nazi nonfiction for children demonstrates how science and story can be exploited to promote a racist agenda.
\end{abstract}

Keywords Children's literature, German - Children's literature in science education · Racism · Holocaust · Anti-semitism · Propaganda · Science · Children's nonfiction · Eugenics

It is commonly known that Nazi ideology was grounded in racist assumptions about biology and nature. The Nazi commitment to the scientific principles of the 1930s, especially ideas from the biosciences, was absolute. At a party meeting in 1934, Rudolf Hess, the deputy party leader, declared, "National Socialism is nothing less than applied biology" (Lifton, 1986, p. 31). It is thus not surprising that Nazi science took the form of a racist story regarding national redemption. What has been less fully recognized are the ways in which racist science and ideological narrative

Daniel Feldman

daniel.feldman@biu.ac.il

1 Department of English Literature and Linguistics, Bar-Ilan University, Ramat Gan, Israel 
tautologically reinforce each other in children's books produced by the Third Reich. At a contemporary moment when race and ideology, science and narrative are once again fueling explosive debates about climate change, racial equity, and public health, children's books from Nazi Germany exemplify an extreme version of how "narratives play a key role in communicating science" (Pauwels, 2019, p. 434) in children's nonfiction. The racist children's nonfiction of the Third Reich demonstrates that when story becomes science and science story without any possibility for "critical engagement" (Sanders, 2018, p. 7), and where questions are posed not to stimulate curiosity, but to reinforce preconceived ideas, the mix becomes toxic. Nazi children's texts offer an instructive, historical example of a society that venerated science to the point of making biology the organizing principle of its educational system, yet produced children's literature shot through with fabrication and falsehood. The following analysis of Nazi nonfiction for children describes how science and story can be exploited to promote a racist agenda.

Scholars have called the Third Reich a racial regime (Pendas et al., 2017, p. 6); it was also a scientific regime. These concepts are not contradictory but rather "two sides of the same coin" (Burleigh and Wippermann, 1991, p. 2). Science played a crucial legitimating function in the Third Reich by furnishing the Nazis with intellectual credibility for their ideological project of creating a new social order of Aryan racial utopia. The regime, in turn, endowed science with prestige, funding, and unprecedented prominence in policy and planning. ${ }^{1}$ Historians have demonstrated that a significant share of "Germany's physicians and biomedical scientists - including leading academics in the related fields of anthropology, eugenics, human genetics, and Rassenforschung (racial science) - were complicit in the eugenic and racial policies of the Nazi regime that culminated in the Holocaust" (Wetzell, 2017, p. 148). While the biological sciences and Nazi political order mutually enabled each other, there was also an irrational quality to the embrace of science in the Third Reich. The Nazis adopted the findings of so-called race science with an enthusiasm bordering on mysticism by inflating the biological sciences to mythic status. At the heart of Nazi ideology was a conception of anti-Semitism that sprouted from contemporaneous biological ideas yet extended into a conspiratorial myth about Aryan salvation that understood "history as the clash of Aryan and non-Aryan forces" and which postulated a "Jewish conspiracy to overthrow Aryan purity" as the gravest threat to German destiny (Stone, 2017, p. 179). For a regime totally committed to a binary logic of inclusion or exclusion drawn from scientific sources, anti-Semitism served as "the mobilizing myth" (Friedländer, 2007, p. 473, emphasis in original). Nazi biology veered into a story about German salvation, eliding any meaningful difference between science and the myth of German historical destiny.

\footnotetext{
${ }^{1}$ For more on science and the state as "resources" benefiting each other, see Mitchell G. Ash, 2001, "Wissenschaft und Politik als Ressourcen füreinander" in Jürgen Büschenfeld Kaderas (ed.), Wissenschaftsgeschichte heute, Bielefeld, pp. 117-134, and Sheila Faith Weiss, 2006, "Human genetics and politics as mutually beneficial resources: the case of the Kaiser Wilhelm Institute for Anthropology, Human Heredity and Eugenics during the Third Reich," Journal of the History of Biology 39, pp. 41-88, https:// doi.org/10.1007/s10739-005-6532-7.
} 
This is the science-cum-myth expressed in Nazi children's books. Three children's books of Nazi propaganda will be analyzed: Elvira Bauer's Trau keinem Fuchs auf grüner Heid und keinem Jud auf seinem Eid (1936), Ernst Hiemer's Der Giftpilz. (1938), and Hiemer's Der Pudelmopsdackelpinscher (1940). These examples provide a powerful and enduring warning of how malicious political actors can recruit science to substantiate warped accounts of reality for the purpose of ingraining their views in children. These texts of lurid racism, all issued by the book publishing arm of Julius Streicher's virulently anti-Semitic newspaper Der Stürmer, offer a monitory case study of how bad science and toxic narrative can coalesce into a literary poison intended to indoctrinate young readers. Science in this corpus becomes a handmaid to nationalist myth, and narrative nonfiction becomes an instrument of repressive authority and racist vitriol. The rhetorical strategies employed in Nazi children's books rebuff critical scrutiny. Rather than stand apart from each other in critical tension, science and story reinforce each other in these texts to urge conformity with racist national ideology. The result is a dangerous convergence of science and story that eliminates any distinction between the two. Anti-Semitic stories are presented in Nazi children's propaganda as expressions of hard science; scientific theories are presented in support of a conspiratorial nationalist myth.

This total integration of science and story fulfilled a major objective of Nazi education, which sought to elevate scientific principles to a central position in German primary and secondary pedagogy during the twelve years of Nazi rule. In Nazi educational theory and practice, racial science ("Rassenkunde") "provided a formative conceptual framework for the entire curriculum" (Wegner, 2002, p. 3). As the glue binding the Nazi curriculum together, racial science sat at the heart of all pedagogical activity, including reading and literary study. There was also no clear distinction between indoctrination and education in Nazi Germany. "The differences between education, propaganda, and education were blurred under the Third Reich," Gregory Wegner writes (p. 106). To the Nazis, racial science provided an explanatory model elucidating the entirety of human behavior and presaging German destiny. Nazi children's books recapitulate the presumption of a biologically established hierarchy of races with the Aryan genotype at its pinnacle by appealing to racist scientific theories reified as fact. Thus did the science underpinning the extreme form of "redemptive" anti-Semitism espoused by the Nazi regime permeate all aspects of its culture (Friedländer, 1997), including children's literature.

\section{Research on Racist Children's Literature}

Children's books in Nazi Germany established a ruinous "architecture of scientific myths" very different from the well-intentioned but embellished accounts of exaggerated scientific discovery that Douglas Allchin identifies in children's books that simply "distort the nature of science" (2003, p. 341 and p. 347). By contrast, the Nazis' grandiose myth of a racial utopia built on Aryan supremacy and the exclusion of ethnic difference was of an entirely different order far beyond the compass of scientific inquiry or historical plausibility. In his comprehensive history of anti-Semitism in Nazi education, Wegner describes how science became inseparable from 
this myth in the Nazi classroom. The following essay is the first to address the same interpenetration of science and historical narrative in Nazi children's books by offering close reading of three works of Nazi children's propaganda that are frequently mentioned in accounts of anti-Semitism but seldom analyzed.

This analysis raises important questions regarding whether and how to draw a line between science and pseudoscience in research on the depiction of science in children's nonfiction. Although biological accounts of Aryan supremacy seem preposterous today (one would hope), whether they should be considered "pseudoscience" is a thornier issue. Wetzell is definitive on the matter:

Most studies have decisively rejected the notion that science under the Nazi regime should be regarded as pseudoscience and have, instead, emphasized the complicity of mainstream, "normal" science with the Nazi regime. This historiographical trend reflects the fact that most historians of science have adopted a sociological definition of science. Thus, according to Robert Proctor, "science is what scientists do"; or, in Sheila Faith Weiss's formulation, "science is what is accepted as science in peer-reviewed journals and funded by scientific agencies." In short, the consensus among historians of science is that we should not impose an anachronistic litmus test of what qualifies as science. If Nazi racial science used scientific forms, methods, and terminologies and was practiced in scientific institutions and recognized by other scientists, then we, as historians, should treat it as science. (p. 159)

Acknowledging that racial science constituted genuine science at its time and therefore should still be considered "science" in historic perspective despite its reprehensible findings forces us to consider that ideas we now see as scientifically valid may one day be repudiated as equally absurd. We can never know which scientific assumptions will be refuted in the future, even as past experience suggests that a good share of our current scientific knowledge will eventually be proved false or inaccurate. By adopting Wetzell's sociological definition of science classifying Nazi racial biology as science rather than as pseudoscience, we avoid the danger of historical superciliousness that would posit contemporary science, education, and children's literature as inherently more sound and therefore more unassailable than the self-evidently bad science, miseducation, and malicious children's books of the Nazis. While Nazi race science has been thoroughly debunked, all science is vulnerable to future contestation or repudiation.

Such receptiveness toward future revision and questioning is at the heart of Joe Sutliff Sanders's theory of children's nonfiction and its literary representation of science. Sanders argues that children's nonfiction enables "critical engagement with ideology" (2018, p. 4). The abuse of science in Nazi children's books offers an extreme example affirming Sanders's contention that study of children's nonfiction can "flag places where nonfiction routinely chooses between inviting and refusing critical engagement" (p. 7). Reading these racist children's texts helps identify worst practices in the translation of science into story by highlighting literary techniques that repel critical engagement and deny any shared authority with the child reader, key tenets of Sanders's theory. The inclusion of Nazi texts in a framework of scientifically-related children's literature can help make critics more cognizant of the 
many ways in which problematic children's nonfiction seeks to short-circuit critical engagement by characterizing scientific ideas as incontrovertible fact, especially when those ideas are endorsed by powerful agents of coercion who demand children's uncritical agreement.

The insistence in Nazi children's books on the young reader's acquiescence also prompts skepticism whether texts of propaganda qualify as literature. In an influential study of propaganda, Jason Stanley defines supporting propaganda as follows: "A contribution to public discourse that is presented as an embodiment of certain ideals, yet is of a kind that tends to increase the realization of those very ideals by either emotional or other nonrational means" (2015, p. 53). Stanley notes that propaganda can be used in the service of "worthy goals, neutral goals, or unworthy goals" (ibid.) and can exist in democratic or repressive societies. This is the definition of propaganda that Bettina Kümmerling-Meibauer and Jörg Meibauer cite in their 2017 analysis of descriptive picture books of the German Democratic Republic in former East Germany. ${ }^{2}$ It is also the model that Julia Mickenberg and Kimberley Reynolds implicitly use in their research on the political uses of science in children's literature in other contexts. I adopt it here to argue that children's propaganda is a category of literature meriting scholarly attention.

By the same token, Reynolds's and Mickenberg's scholarship indicates that Nazi exploitation of biology in children's books contrasts sharply with the invocation of science in texts of radical British literature for young readers during the 1930s and 1940s (Reynolds, 2016) and in leftist children's texts of postwar Cold War America during the 1950s and 1960s (Mickenberg, 2005). British authors of radical children's literature of the 1930s and 1940s employed scientific themes to advance their aims of "helping their readers mature into rational, fulfilled, capable adults by arming them with the skills and information they would need to interrogate their surroundings and decide what they wanted to think and believe" (Reynolds, p. 2). In Britain, this depiction of science took an overtly political cast. Reynolds chronicles a "cluster of radical children's books" that depict the Soviet Union as a "grand experiment in which technology and the sciences ... were being used to plan and deliver a new way of managing society" (p. 74). Science was endowed with the imprimatur of technocratic efficiency and egalitarian equity. This contrasts with the deep social divisions justified by the findings of racial biology promulgated in works of Nazi propaganda. Mickenberg reports that American authors of postwar children's literature saw in science a vessel for buttressing ideology but not an ideology in itself. She documents how American educators and writers of all political stripes in the 1950s and 1960s dramatically raised the profile of science in the wake of the cultural and educational crisis sparked by early Soviet successes in the Space Race. Left-wing authors of children's books were especially active in writing texts that leveraged science to "communicate their social values to children," Mickenberg writes (p. 182).

\footnotetext{
${ }^{2}$ Bettina Kümmerling-Meibauer and Jörg Meibauer, 2017,» Keines zu klein, Helfer zu sein «. Das deskriptive Bilderbuch in der DDR zwischen Information und Propaganda. In Sebastian Schmideler, ed. Wissensvermittlung in der Kinder- und Jugendliteratur der DDR. Göttingen: V \& R unipress. pp. 26793, http://doi.org/10.14220/9783737006781.267.
} 
Here, too, a scientific outlook was identified with cultivating a critical perspective. Some progressive authors promoted the view "that science study should teach children a questioning attitude toward all received authority, teach them to test all of their hypotheses and to see their limitations, and teach them to see the social and ethical implications of science" (p. 185). This progressive, socialist use of science in leftist American children's texts of the 1950s and 1960s Cold War again stands in stark contrast to the use of science in children's literature of the far-right, nationalist Third Reich, in which science was deployed to squelch dissent and compel submission to authority.

Nazi children's propaganda also serves as an uncomfortable reminder of the enduring role of racist science in mainstream children's literature, since the Nazis were not the first to ground children's books in race science. Eugenics have long featured in American children's books. ${ }^{3}$ Karen Keely demonstrates that Jean Webster's early twentieth-century American classic youth novels Daddy-Long-Legs and Dear Enemy reflect the author's abiding interest in hereditarian science and eugenics, a topic of widespread discussion in American reform and policy circles during the early decades of the twentieth century. "Webster became increasingly convinced by hereditarian reasoning and used her novels as a medium for didacticism on the subject," Keely writes (2004, p. 364). The narrator of Dear Enemy enumerates the elements of a solid grasp of the biosciences in her day: "A person in my position ought to be well read in physiology, biology, psychology, sociology, and eugenics" (Webster, 1915, p. 90). Webster's support for eugenic policies, such as "involuntary sterilization or segregation of the mentally disabled" (Keely, p. 364), is reflected in the narrator's dalliance with radical proposals: "I do hate to poison the child, but what can I do?" she asks with dark humor (Webster, p. 107). ${ }^{4}$

Interest in eugenics also preoccupied a "significant piece of children's literature" in late Victorian and Edwardian Britain, Jessia Straley argues. Eugenics, she states, helped spawn tales of "violent adventures and [...] idealistic romances for girls" (2016, p. 160). Amanda Hollander likewise shows that E. Nesbit's 1909 Harding's Luck from the House of Arden series was influenced by eugenic theories disseminated by the Fabian Society, which she co-founded (Hollander, 2017). Reading the appalling scientifically-based racism portrayed in Nazi children's books may, therefore, prompt salutary awareness of comparable interest in eugenics that flourished in the United States and England.

\footnotetext{
3 The genre of writing based on eugenics, which Seitler calls American "regeneration narratives," was hardly limited to children's literature but instead encompassed many categories of American texts (2003).

4 Webster was not eccentric in her promotion of eugenics in early twentieth-century America. Twentyfive states enacted sterilization laws in the early twentieth century reflecting the nation's "history of coercive and sometimes illegal sterilization" (Lifton, 1986, p. 22). In 1933, the year of the Nazi ascent to power, eugenics research and policy initiatives in the United States so far outstripped contemporaneous efforts at hereditary reform in Germany that some German racial theorists lamented that "Germany had no equivalent to the American laws prohibiting marriage both for people suffering from such conditions as epilepsy or mental retardation, and between people of different races" (p. 23). For more on the mutual influence among American and German eugenics advocates, see Stefan Kühl, 1994, The Nazi Connection: Eugenics, American Racism, and German National Socialism, New York.
} 
Nor was Germany the only fascist state to issue propaganda as children's literature. Extreme right regimes in Italy, Spain, and France similarly published children's books about the birth of a "new" national community based on nativist heritage or shared racial traits (Giorgi, 2012; McLean, 2018; Proud, 1998). In different settings, this children's propaganda assumed disparate forms. For instance, Judith Proud's study of French children's books adulating the Vichy regime led by Maréchal Pétain notes that Vichy children's propaganda coopted the traditional genre of the French fairy tale as an expedient means of communicating the regime's values to young readers. "By emulating a familiar and well-loved form of literature, authors facilitated access to their young audience through immediate appeal and comprehension of the genre," Proud says (p. 19). In contrast, the dependence on narratives drawn from the biological sciences in children's texts of the Third Reich reflects the unique status of biology in Nazi children's literature and education.

\section{Poisoning Minds}

One of the most prominent children's books of the Nazi period, Hiemer's Der Giftpilz (The Poisonous Mushroom) instantiates the toxic combination of science and narrative in a text featuring Nazi eugenics as the biological justification for antiSemitism. Written by an editor of Der Stürmer, which published the book (Bytwerk, 2001, p. 105), the text offers sixteen illustrated scenes depicting the alleged perfidy of the Jews. The book's title chapter, "The Poisonous Mushroom," vividly exemplifies the conflation of racist biology and narrative. The vignette portrays a mother and her young son gathering mushrooms in a bucolic German forest. The illustration (Fig. 1), by Der Stürmer's in-house cartoonist, the notorious Nazi artist Philipp Rupprecht (known as Fips), shows a stereotypically blond mother and child dressed in traditional folk garb resembling dirndl and lederhosen; the pair's sartorial bona fides signify their genetic authenticity as pureblooded Germans. The boy picks some poisonous mushrooms, prompting a lesson from his mother about the importance of discerning edible from poisonous mushrooms. Species may look alike but carry diametrically opposed consequences for health, she says. This metaphorical lesson in the vital significance of discriminating between superficially similar but organically different fungi swiftly "mushrooms" into racist instruction regarding the stakes of preserving the putative genetic and biological purity of Germans. The mother encourages her son to draw connections between mycology and society:

"Schau, Franz, mit den Menschen auf der Welt ist es genauso wie mit den Pilzen im Wald. Es gibt gute Pilze und gute Menschen. Es gibt aber auch giftige, böse Pilze und böse Menschen. Und wir müssen uns vor bösen Menschen hüten genauso wie vor giftigen Pilzen. Verstehst Du das?"

(Hiemer, 1938, p. 7)

["Look, Franz, human beings in this world are precisely like mushrooms in the forest. There are good mushrooms and there are good people. But there are also poisonous, bad mushrooms and there are bad people. And we must 


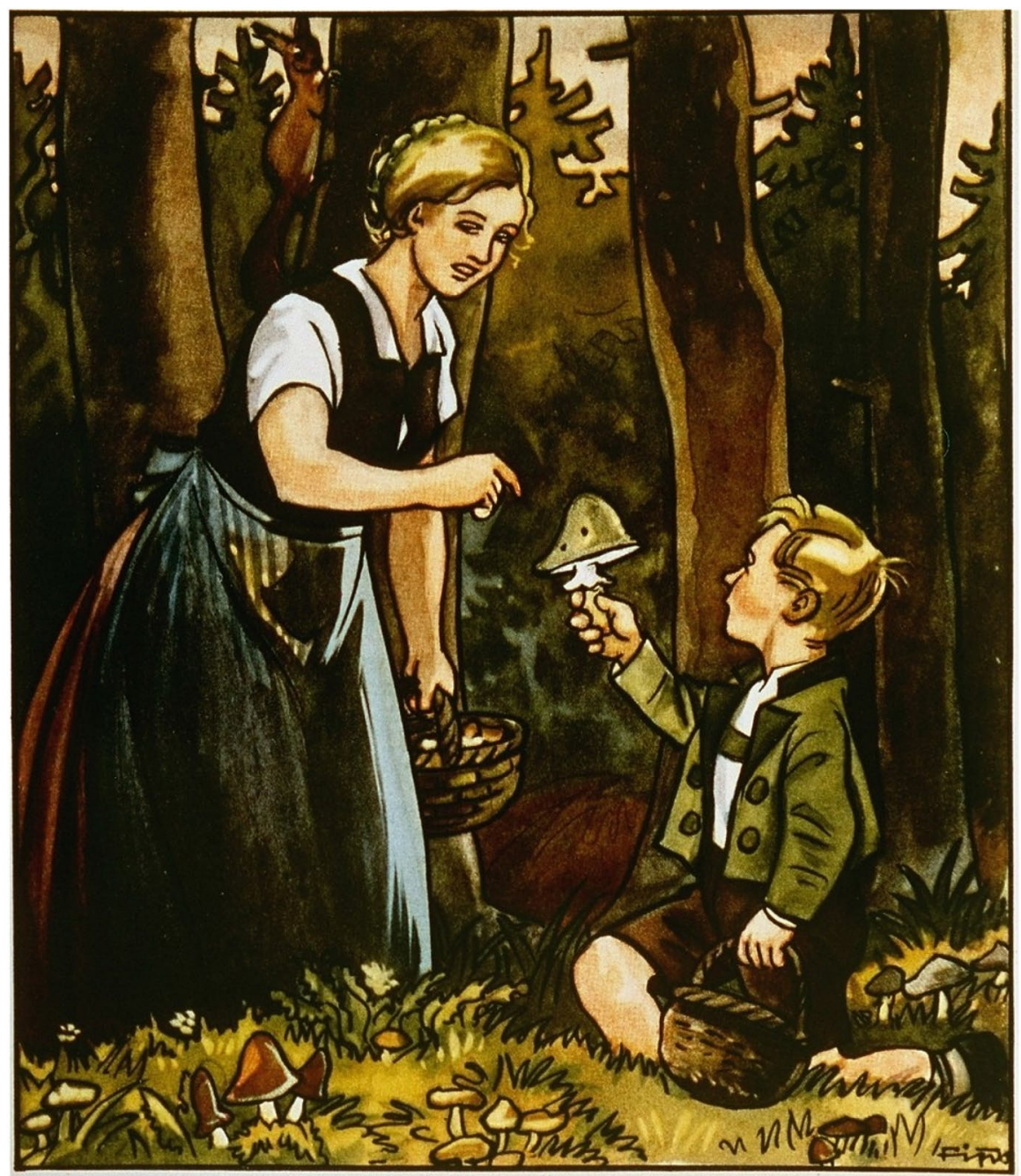

„WBie die (5iftpilze oft id)wer von Den guten Bilzen zu unterid)eiden find, io ijt es oft (eh) iđ)wer, die Juben als (5auner und Berbred)er zu erfennen..."

Fig. 1 Illustration for "The Poisonous Mushroom." The caption reads, "Just as it is often hard to tell the poisonous mushrooms from good mushrooms, so too it is very difficult to recognize the Jew as a crook and criminal..." Copyright: United States Holocaust Memorial Museum, "Available for Research" https://collections.ushmm.org/search/catalog/pa1069700

beware of bad people just as we must beware of poisonous mushrooms. Do you understand that?"].

As a duly educated Nazi youth, the boy replies that he already grasps what his mother asks. "Ja, Mutter" ("Yes, mother"), he answers. He then continues, "Ich 
verstehe, dass man durch Verhandeln mit schlechten Leuten in Schwierigkeiten kommen kann, genauso wie wenn man einen giftigen Pilz isst. Mancher stirbt sogar dran!" ("I understand that dealing with bad people can make trouble for you, just as when you eat a poisonous mushroom. Some even die from it!") (ibid.). Elaborating on the fallacious assumption that some people are inherently "poisonous" to the well-being of humanity, Franz's mother steers the discussion away from forest ecology and toward national biology. "Und weißt Du auch, wer diese schlechten Menschen sind, die Menschlichen Giftpilze?" ("And do you know who these bad people are, these human poison mushrooms?"), she asks her son. "Natürlich," ("Of course"), the boy proudly answers, "Das sind die Juden. Unser Lehrer hat uns oft über sie erzählt!" ("They are the Jews! Our teacher often told us about them"). The text's potent concatenation of bad science, racist narrative, and pernicious education is laid bare. The vignette conflates science and story in a paradigmatic example that pivots from the responsible management of natural resources to the policing of race relations, a duty that falls with equal weight upon children and adults and that constitutes the proper focus of Nazi education.

The dialogue issues a call to recruit German youth into the effort to preserve the genetic integrity of the Aryan race. The son asks his mother if all non-Jews share in his cognizance of the Jewish threat, which he has already learned from his teacher and parent:

"Sag mir, Mutter, wissen alle Nichtjuden, dass der Jud so gefährlich ist wie ein Giftpilz?"

Die Mutter schüttelt den Kopf. "Leider nicht, mein Kind. Es gibt Millionen Nichtjuden die die Juden noch nicht kennen. Darum müssen wir die Leute aufmerksam machen und vor den Juden warnen. Unsere jungen Leute müssen genauso gewarnt werden. Unsere Jungen und Mädchen müssen die Juden kennen lernen. Sie müssen lernen, dass der Jude der giftigste Pilz ist, den es gibt." (Hiemer, 1938, p. 8)

["Tell me, mother, do all non-Jews know that the Jew is as dangerous as a poisonous mushroom?"

The mother shakes her head. "Unfortunately not, my child. There are millions of non-Jews who do not yet know the Jews. That's why we have to make people aware and warn them about the Jews. Our young people, too, must be warned. Our boys and girls must learn to recognize the Jew. They must learn that the Jew is the most dangerous poisonous mushroom that there is."]

The child asks his mother whether other non-Jews, presumably including his young German peers, recognize the peril of the Jewish threat and the exigency of safeguarding their genetic pool from the imminent danger of the human "poison mushroom." "Do all non-Jews know that the Jew is as dangerous as a poisonous mushroom?" the child asks. The mother answers her son's query with regret: too few non-Jews share her son's precocious insight. Their exchange emphasizes the need to inculcate the same awareness in other German children. Loyal, patriotic, and effective education, the text insinuates, ought to apply the racist lessons of biology to the social sphere so as to bring into being the ethnic and nationalist community of 
Aryans that would fulfill Nazi ideology. A legitimate lesson about subtle differences in nature is applied without qualification to differences in society in order to support an ideological fantasy. Thus does the text subordinate science to a racist story, even as the Nazi myth poses as science.

The narrative also distorts what Zarnowski and Turkel call the nature of science, namely authentic scientific inquiry that is "subject to change" and tied to "no single" method (2013, p. 296). Rather than represent science as subject to falsification and fallibility, Hiemer's account promotes a conception of scientific knowledge that is monolithic, absolute, and impervious to questioning. The text demonstrates how such a spurious notion of science can come to infect discrete disciplines, in this instance biology and literature, and corrupt separate generations, specifically parents and their children, in order to repel any challenge to received ideology. Dialogue in "The Poisonous Mushroom" develops as a series of questions and answers exchanged between mother and child about shared knowledge: "Do you understand?" "I understand." "And do you know?" "Of course." "Do all non-Jews know?" "Millions do not yet know." In this racist context, however, "knowledge" means acceptance of mendacity. As a proxy for the German child reader, the boy in the story is inducted into the privileged structure of repressive authority that invites those who possess conspiratorial "knowledge" of racial biology to join in the defense of humanity against the alleged Jewish menace. Appallingly, this purported "truth" is, in fact, a vicious lie. In contrast to questions that "provoke reflective engagement with information" or activate a collaborative and skeptical "sharing of authority between books and children" in Sanders's exemplary model of interrogative reading (pp. 6-7), the questions in Hiemer's text create a closed epistemological circle in which what is asked is that which the child already knows- "Do you understand?" "I understand" "Do you know?" "Of course." The discussion leads not to inquiry or curiosity but instead confirms existing assumptions, thereby eliminating any possibility for doubt, uncertainty, or critical engagement. Questions serve not to probe or extend knowledge but to reinforce what one already believes or hears. In the text's hermeneutically sealed and intellectually tautological world in which science is story and story science, there is no real need to ask questions, for the answers are already known. There is no "cracking open the polished surface of the authority of texts" in order to reveal spaces in which children can "ask questions, test information, and become part of the process of intellectual inquiry" (Sanders, pp. 11-12). All uncertainty is rebuffed in this story, which invites children to become part of the ideological power structure rather than its skeptical interrogators. Indeed, the Nazi child in the text is incredulous only that not all non-Jews know what he knows, and he becomes an agent in helping to proselytize the conspiratorial truth to other German children.

The next scene in The Poisonous Mushroom portrays such indoctrination at work (Fig. 2). The story, "Wie man einen Juden erkennt" ("How to recognize a Jew") depicts the school system colluding with children's books and racist science to crush independent thought and validate the regime's scientific premises about race. Set in the classroom of "Mr. Birkmann," the vignette captures a touchstone moment in Nazi pedagogy: the students are learning how to recognize the biological traits of Jews. The teacher has drawn several images on the blackboard 


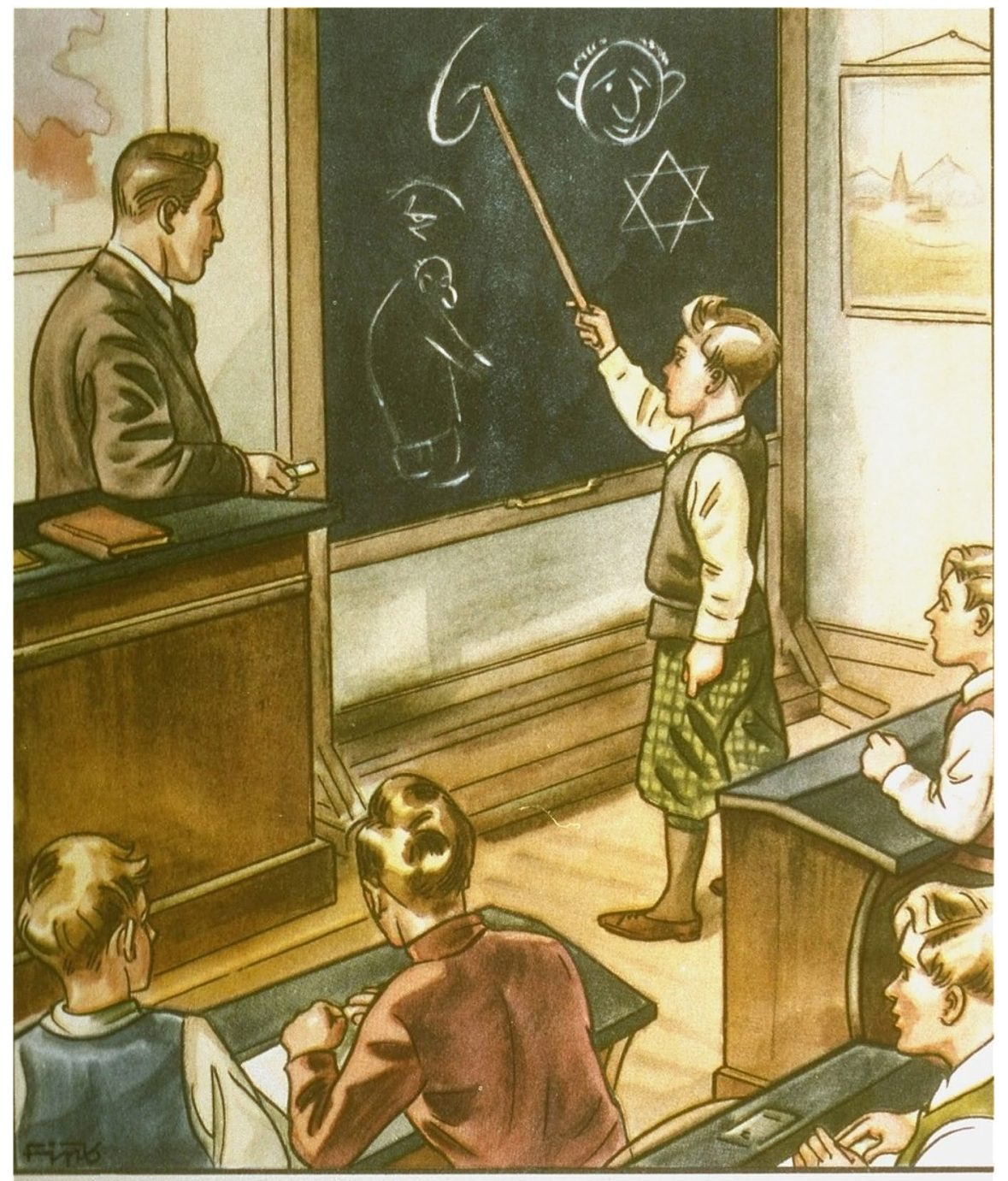

"Die Jubennaje ijt an ihrer Spibe gebogen. Sie jieht aus wie ein Ged)jer..."

Fig. 2 Illustration for "How to recognize a Jew" from The Poisonous Mushroom." The caption reads, "The Jewish nose is hooked at its tip. It looks like a six..." Copyright: United States Holocaust Memorial Museum, "Available for Research" https://collections.ushmm.org/search/catalog/pa1069702

and then invites students to analyze the drawings. One student stands before the board and explains the sketches to his classmates:

"Erstens erkennt man einen Juden an seiner Nase. Die jüdische Nase ist hakenförmig. Sie sieht aus wie die Form 6. Darum nennen wir sie 6er- för- 
mig. Viele Nichtjuden haben genauso Hakennasen. Aber in ihrem Falle sind die Nasen dann nach oben krumm, nicht nach unten. Das hat nichts mit der jüdischen Nase zu tun." (p. 11)

["One first recognizes a Jew by his nose. The Jewish nose is hook-shaped. It looks like the number six, which is why we call it the 'six-shaped.' Many Gentiles also have hooked noses, but in their case the nose bends up, not down. This has nothing at all to do with a Jewish nose.’]

Two apodeictic disciplines based on quantifiable fact, mathematics and biology, are manipulated in this vignette to convey a perfidious deceit about physiognomy and race. Jews are assumed to exhibit fixed if subtle physiological attributes that the perceptive observer can learn to detect. Child readers of Hiemer's book, like the pupils in the scene depicted in the story, receive training in these nuanced physical cues, the better to spot and defend against Jews. The crux of this brief narrative is to make Nazi biology and children's literature theoretically congruent and mutually complicit in indicting Jews. Each discourse is simply a pretense for the other. The balance of the vignette portrays students eagerly traipsing to the blackboard one after another to add further detail to the description of Jews. Members of the class, and by extension the book's intended readership, become young cognoscenti, informed experts wielding cutting-edge science to identify and isolate the Reich's enemies. By offering narrative depiction of how to apply biology in the classroom, this story stages the paradigmatic merger of pedagogical indoctrination, scientific racism, and children's propaganda to fulfill the ideological mandate of the state.

\section{Toxic Texts}

The book's message was broadly heeded. German teachers greeted The Poisonous Mushroom with enthusiasm. The text went through four printings totaling 40,000 copies and was widely distributed among educators (Bytwerk, p. 172). Christa Lufer, a child diarist, wrote in her journal of the spring day in May 1938 when her teacher rapturously read from Hiemer's book and thus, unwittingly, granted her a reprieve from having failed to complete her homework, a more pedestrian and common childhood concern than fear of national corruption through genetic mixing. Lufer writes:

Yesterday was the first warm day this year. I played outside all day and completed none of my homework for German. I was therefore a little anxious when I went to school this morning. Herr Wenzel always shouts with the same loud voice. But I was lucky. Herr Wenzel spent the entire hour talking about a new book that absolutely should be purchased by our parents. In order not to be required to show my homework, I listened with an especially sharp ear. The book was edited by Der Stürmer. It is a book for children and adults with many beautiful pictures. Every good German must read the book, Herr Wenzel said. It states the dangers threatening the German people from the Jews. Herr Wenzel read to us from the first story. It is called, "The Poison Mushroom." 
The story stated that the Jews are poison mushrooms and the we must watch out for them. (Wegner, p. 159)

As this juvenile account attests, "The Poisonous Mushroom" is an aptly titled work, for the text compelled German children to read literary poison. German children avidly imbibed this narrative poison with its exhortation "to learn to know the Jew" (p. 10).

Two other books produced by the same publisher, including another text by Hiemer, mount equally malevolent anti-Semitic attacks prosecuting a case of biological racism against Jews. Hiemer's 1940 Der Pudelmopsdackelpinscher (The PoodlePug-Dachshund-Pinscher) addresses young readers in the same terms of toxicity broached in his 1938 mushroom story, though conveyed here via an analogy between poisonous snakes and Jews (Fig. 3). Unlike inanimate fungi, venomous snakes are characterized in The Poodle-Pug-Dachshund-Pinscher as willfully malicious in their spread of deadly poison: "Mitleidslos fallen sie über das ahnungslose Tier her. Mit dem Bisse ihrer Zähne vergiften sie das Blut ihres Opfers" ("They mercilessly attack the unsuspecting animal. With the bite of their fangs they poison their victim's blood") (p. 67). Not only are snakes deliberately cruel in their assault on unwitting victims, but their method of attack is diabolical in its treachery, since snake toxin does not incapacitate immediately but rather overwhelms the victim gradually:

Wenn Menschen von einer Giftschlange gebissen werden, tritt allerdings der Tod nicht so schnell ein. Zuerst spüren sie nur eine langsame Ermüdung des Körpers. Die Kräfte sinken. Schwindelanfälle folgen. Der Blutdruck verändert sich. Dann treten starke Blutungen aus den Mund, Nase und Ohren ein. Während manche der Gebissenen bald darauf das Bewußtsein verlieren, müssen aber die meisten von ihnen unter fürchterlichen Schmerzen langsam dahinsterben. (Hiemer, 1940, p. 68)

[When people are bitten by a poisonous snake, death does not occur so quickly. At first they only feel a slow fatigue of the body. Their strength falters. Dizzy spells follow. Blood pressure changes. They start bleeding heavily from the mouth, nose and ears. While some of those bitten quickly lose consciousness, most die slowly in excruciating pain.]

The toxic analogy is spelled out in the text: "Wie die Giftschlangen durch ihren Biß das Blut ihres Opfers vergiftet, so vergiftet der Jude seine Gastvölker" ("As the snake poisons the blood of its prey through its bite, so does the Jew poison its host nations") (p. 71). Nations that allow Jews to "poison" the supposed purity of their blood pool gradually succumb to lethal infiltration while remaining nearly oblivious to their encroaching incapacitation, the text says: "Menschen, die sich mit den Juden einlassen, verlieren die Reinheit ihres Blutes. Anfänglich merken sie es kaum, wie das jüdische Gift ihren Körper und ihre Seele zerfrißt. Langsam sinken sie aber von Stufe zu Stufe" ("People who let in the Jews lose the purity of their blood. At first they hardly notice as the Jewish poison infects their bodies and souls. But slowly, step by step, they decline") (p. 71). The pedagogical message was not metaphorical but literal: the Nazi prohibition on so-called "miscegenation" or mixing of races enforced by the 1935 Nuremberg Laws was portrayed in Nazi educational materials as based on science, evident in these 


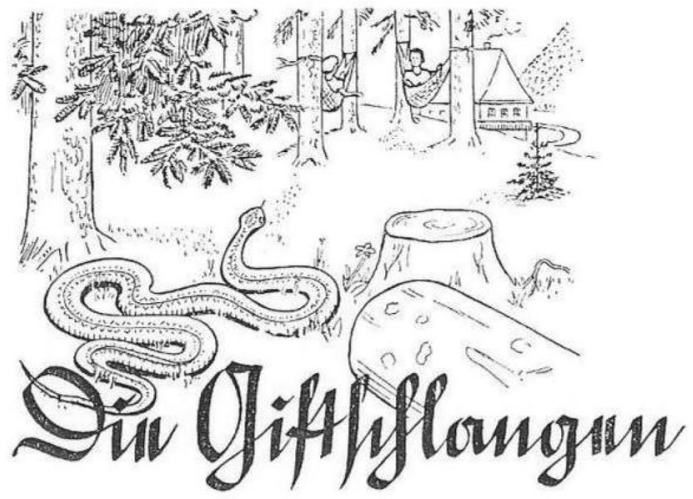

Sinter einem fdbutcen Bauernbaus im Sd)warzwalb! 3roei junge Mäbd)en liegen in Sängematten uno id)aufeln luftig bin und ber.

,Sier mö(t)te ich immer bleiben! Bei eud) ift es wunder= [c)ön!" Go jagt bas vierzebnjäbrige Jungmäbel Jnge aus $\mathfrak{B} e r=$ Iin zu ibrer Freundin Elfe. "Jhr auf bem \&ande riißßt ja gar nid)t, wie gut ibr es babt. Jbr tennt nicht ben Rärm Der Stra=

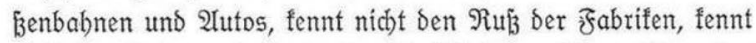

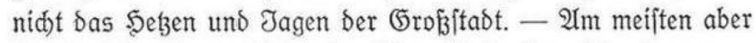
beneibe ich eud) um biejen berrlitfen Rubeplat. Sier fann man fich) Straft bolen jelbit für bie fówerfte 3eit."

Jnge idjweigt und atmet tief bie roüroige Ruft ein, bie aus bem gebeimnisvollen 2 albe berüberitreict)t. Plögliç) fäbrt fie in bie Söbe.

,Du, Elfe, was ift Denn Das für ein grofjer $\mathfrak{B}$ urm, ber da borne unter bem Baume liegt?"

Elje blidt bin. Sie erid)ridt und flüftert:

Fig. 3 Illustration for "The Poisonous Serpent" from The Poodle-Pug-Dachshund-Pinscher. Internet Archive, Open Source collection (no copyright) https://archive.org/details/ernst-hiemer-der-pudelmopsd ackelpinscher-1940-50-s.-scan-fraktur/page/60/mode/1up

images (Fig. 4 and Fig. 5) from Alfred Vogel's 1938 Erblehre und Rassenkunde in bildlicher Darstellung, a visual teaching aid on Nazi science, that compare the genetic mixing of flora and humans. These images supported a textbook on race science that cites Mein Kampf and examples from nature to teach children that "the result of race mixing, in brief, is always a) the lowering of the quality of the higher race, and b) a physical and spiritual decline" (Bareth and Vogel, 1937, p. 46). The intermingling of races was thus made palpably terrifying for children in the Third Reich as the source of national decay that inexorably leads to total social collapse. Hiemer's analogy between serpentine venom and insidious Jewish contamination of national bodies is supposedly biological. Yet the toxicity of the text's analogical thinking lies not in the accuracy of 
its herpetological claims, but in the dubious applicability of zoological traits to humans. For Nazi exponents of race science, biological ideas illuminated political dogma. "What held for the plant and animal kingdoms also held true for the German body politic," Wegner writes (Hiemer, 1940, p. 108). To Hiemer and fellow ardent Nazis, this total integration of science with the story of Germany social renewal proved the veracity of the national myth seen in the crux of this children's tale.

The cogency of any metaphor lies in the assumption that both tenor and vehicle share the same frame of reference. In Nazi ideology, biological and social realms are mutually imbricated in a way that makes the toxin of the snake evocative of the alleged subversiveness of Jews. For the critical reader interpreting the text with different intellectual coordinates, however, another analogy suggests itself in the way that Hiemer's narratives metaphorically poisoned young minds. Unsuspecting child readers of this propaganda may not, at first, have taken notice of the literary "poison infecting their bodies and souls" ("Anfänglich merken sie es kaum, wie das Gift ihren Körper und ihre Seele zerfrißt") or immediately succumbed to the malicious agenda of such racism. But once the venom of hatred was injected into impressionable, "unsuspecting" ("ahnungslose") young minds, the poisonous effects of these works were nearly impossible for children to escape until "slowly, step by step, they declined" into moral turpitude and confusion ("Langsam sinken sie aber von Stufe zu Stufe"). Incrementally but purposefully, Hiemer's books may have caused German children of the Third Reich to experience the same "faltering of strength" ("Die Kräfte sinken"), debasement of innocent "purity" ("verlieren die Reinheit"), and loss of independent critical "consciousness" ("das Bewußtsein verlieren") that the snake vignette attributes to victims of so-called Jewish serpents. The most vivid analogy for the debilitating effects of reading such narrative poison, then, comes from the text itself.

\section{Against Diversity}

The Poodle-Pug-Dachshund-Pinscher consists of twenty-two sketches of animals and organisms from the natural world, including, in addition to snakes, hyenas, locusts, bedbugs, and, predictably, bacteria, whose biological characteristics are ascribed to Jews. The organizing principle of the text is that knowledge of nature's supposedly most despicable creatures will better acquaint young German readers with the many nefarious qualities of Jews. The Jew is portrayed less as part of human civilization than as a part of nature-or, more specifically, a perversion of nature, since Jews are also said to resemble the mongrel of the book's title whose absurdly heterogenous breeding makes a mockery of pedigrees. Like the grotesque mutt, Jews are also of eclectic ancestry, the text states: "Auch die Juden sind Mischlinge" ("The Jews are also mixed breeds") (p. 61). Jews are said to exhibit the worst traits of the various "weißen, gelben, und schwarzen Völkern" ("white, yellow, and black people") from which they descend. In this view, Jews are not really a race at all but a mixture of other races. Such scorn reflects the Nazi fanaticism for racial purity. Contrary to modern views of biology, biodiversity and genetic mixing were seen as degenerate in the biology of the Nazi period. Scientists who challenged this scientific and political orthodoxy risked running foul of the regime (Wetzell, p. 


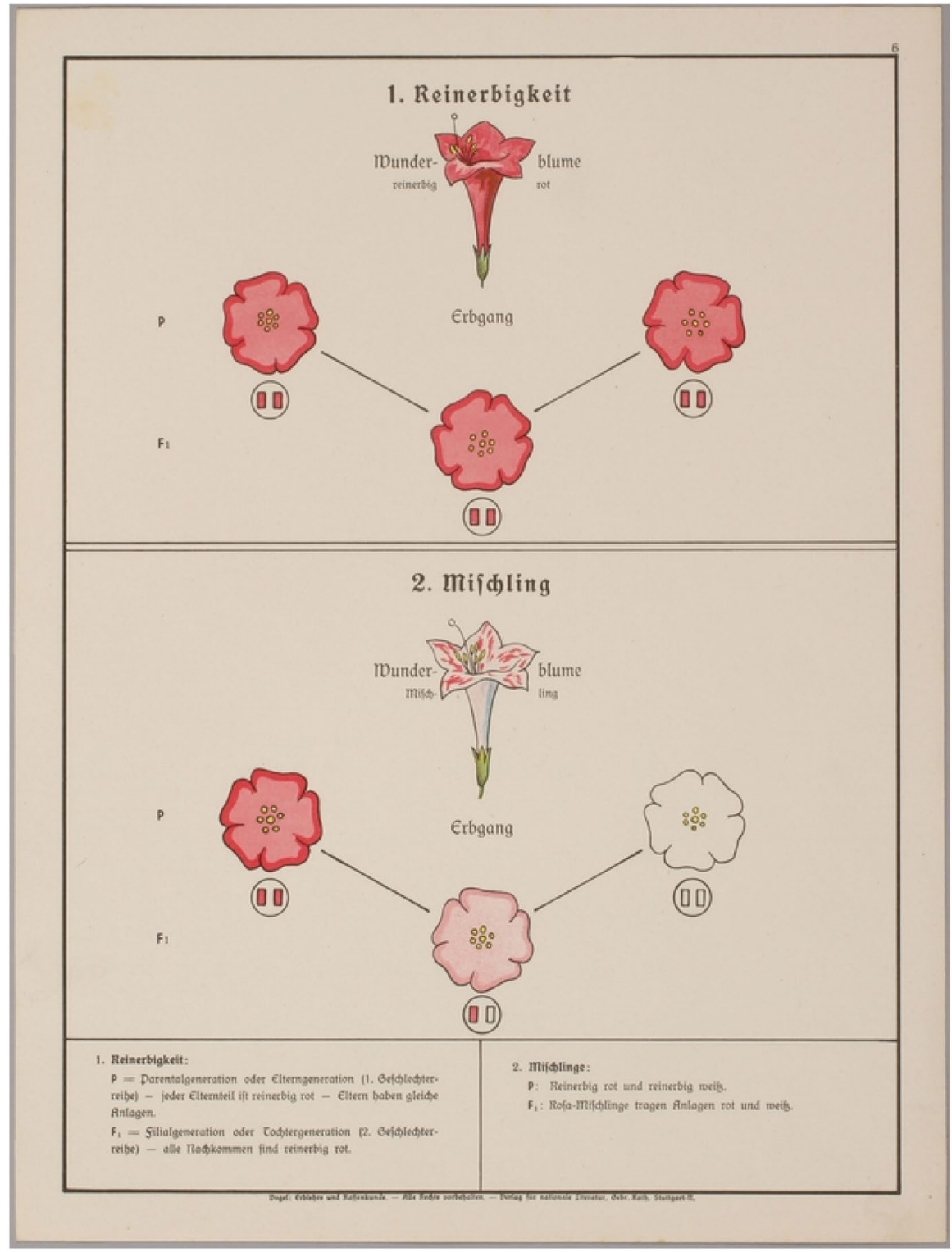

Fig. 4 Visual illustration of the deleterious effects of mixing genetic breeds from the Nazi teaching aid Erblehre und Rassenkunde in bildlicher Darstellung. The upper half depicts genetic "purity," the bottom half "mixed-breed." United States Holocaust Memorial Museum, "No restrictions on access" "https:// collections.ushmm.org/search/catalog/irn531092 


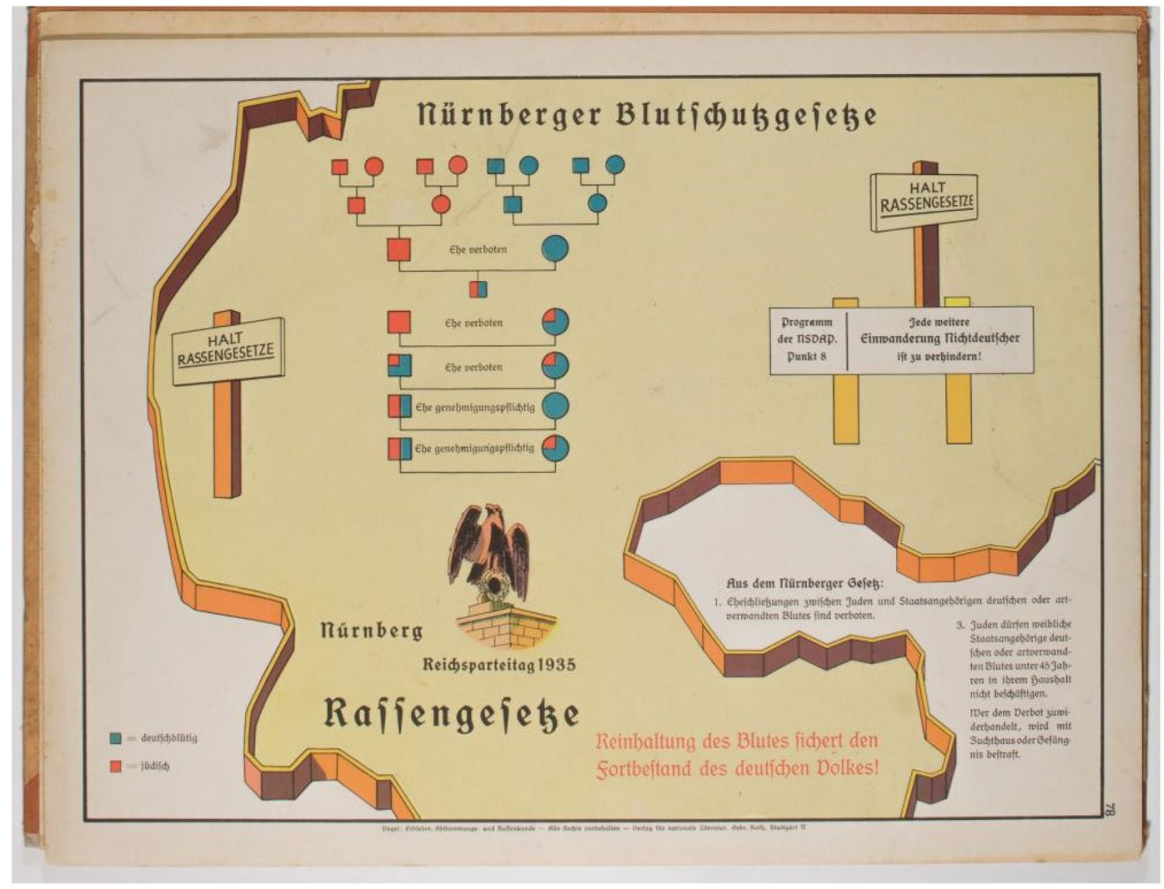

Fig. 5 Visual illustration of the Nuremberg Laws forbidding marriage between Jews and Germans, from the Nazi teaching aid Erblehre und Rassenkunde in bildlicher Darstellung. The slogan in red states, "Keeping the blood pure secures the survival of the German nation." United States Holocaust Memorial Museum, "No restrictions on access" "No restrictions on use" https://collections.ushmm.org/search/catal og/irn2585

152). German youth, especially girls, were instructed to keep German blood pure since, they were told, "maintaining purity of blood is in the interest of all valuable races" (Stone, p. 179). This scientific consensus reflected the Nazi ideology portrayed in Hiemer's stories.

Hostility to diversity in either society or nature is evident in all three children's books published by Der Stürmer. The Poodle-Pug-Dachshund-Pinscher also compares Jews to chameleons for their propensity to change appearance, even as their mutability remains constant_- "Ein Chamäleon bleibt ein Chamäleon, und ein Jud bleibt ein Jud!" (“A chameleon remains a chameleon and a Jew remains a Jew!") (Hiemer, 1940, p. 31). Bauer's Trau keinem Fuchs auf grüner Heid und keinem Jud bei seinem Eid (Trust No Fox on his Green Heath And No Jew on his Oath) follows a similar line of thought by declaring the biological fixity of all people and organisms despite Jews' attempts to adulterate the German polity. In "Jud bleibt Jud" ("A Jew remains a Jew"), Bauer warns young readers as a rationale for rejecting the legitimate conversion of baptized Jews (p. 11). Official Nazi race science vehemently opposed all genetic diversity. Moreover, state biology conceived of people, animals, and plants as intrinsically positive or negative based on their presumptive benefit to 
the German people. The preeminence of Germans atop a static natural hierarchy is taken for granted as a scientific fact. The logical implication is clear: "Biology, by its very nature, was bound up in ethical and ideological questions" that "could only become evident for pupils if they were challenged to think about applying the laws [of nature] to larger human issues," Wegner writes (p. 101).

The work of synthesizing biology with ideological tenets is conceptually framed in Bauer and Hiemer's texts as a repudiation of any distinction between various systems of thought. Whereas scientific inquiry fosters a multiplicity of analytic perspectives and champions the diversity of life and knowledge, Nazi racial science demands uniformity of thought and fetishizes pureblooded ancestry. If children's books based on the work of contemporary science seek to cultivate skeptical challenge and informed critique, historical propaganda books based on racism demand ideological acquiescence and enthusiastic assent. The conspiratorial point of view championed in Nazi children's books dictates that the faithful reader see all of reality as a unitary secret to be unravelled; in exposing that secret, these texts conflate discrete intellectual disciplines while dismissing difference and diversity. Thus, the repressive ideology that disdains biological diversity among people and organisms likewise admits no epistemological difference between science and literature, nature and society, or biology and politics - there is only one way of viewing the world.

This total consolidation of science and story, information and ideology in Nazi children's literature is epitomized in a sequence of pages late in Bauer's text that casts Julius Streicher, the publisher of the book and its parent newspaper, Der Stürmer, as a healer, teacher, and savior of German youth as well as patron of children's literature. Streicher was a former school teacher who was obsessed with Jews (Bytwerk, pp. 1-30). In Bauer's account, however, Streicher first appears as the antagonist to a craven Jewish doctor who plies his non-Jewish patients with medicine that is in fact poison. ${ }^{5}$

Punning on the publisher's name, the text says that Streicher sees through these duplicitous Jewish "Streiche" ("antics") and restores health to Germans by prescribing the antidote to the Jewish toxin (Fig. 6): "Er hat die Juden all gelehrt,/Was ein gesundes Volk ist wert" ("He's taught a lesson to all the Jews/About what a healthy nation values") (Bauer, p. 31). As symbolic bringer of health and wholesome truth, Streicher segregates Jew from German so that education becomes more pleasing: "Nun wird es in den Schulen schön;/Denn alle Juden müssen gehn" ("Now it's nice in the schools/Since all the Jews must leave") (p. 39). To teach faithfully is also to heal the sick in body and spirit. Further lauding Streicher, the text suggests that he stands behind a global exposé of the putative Jewish threat; the text extolls Streicher's Der Stürmer for having inspired newspapers the world over, "even in America," to take up the cause of anti-Semitism (p. 33). This encomium to Streicher as healer of Germany, educator of its youth, muckraking correspondent of anti-Semitic "truth," and publisher of the book that the child is now reading reflects a sweeping amalgamation of the separate discourses of knowledge that these roles represent:

\footnotetext{
5 Notably, the poisonous medicine is thrice referred to as "die Mixtur," "the mixture," further evidence of the Nazi antagonism toward blended components.
} 


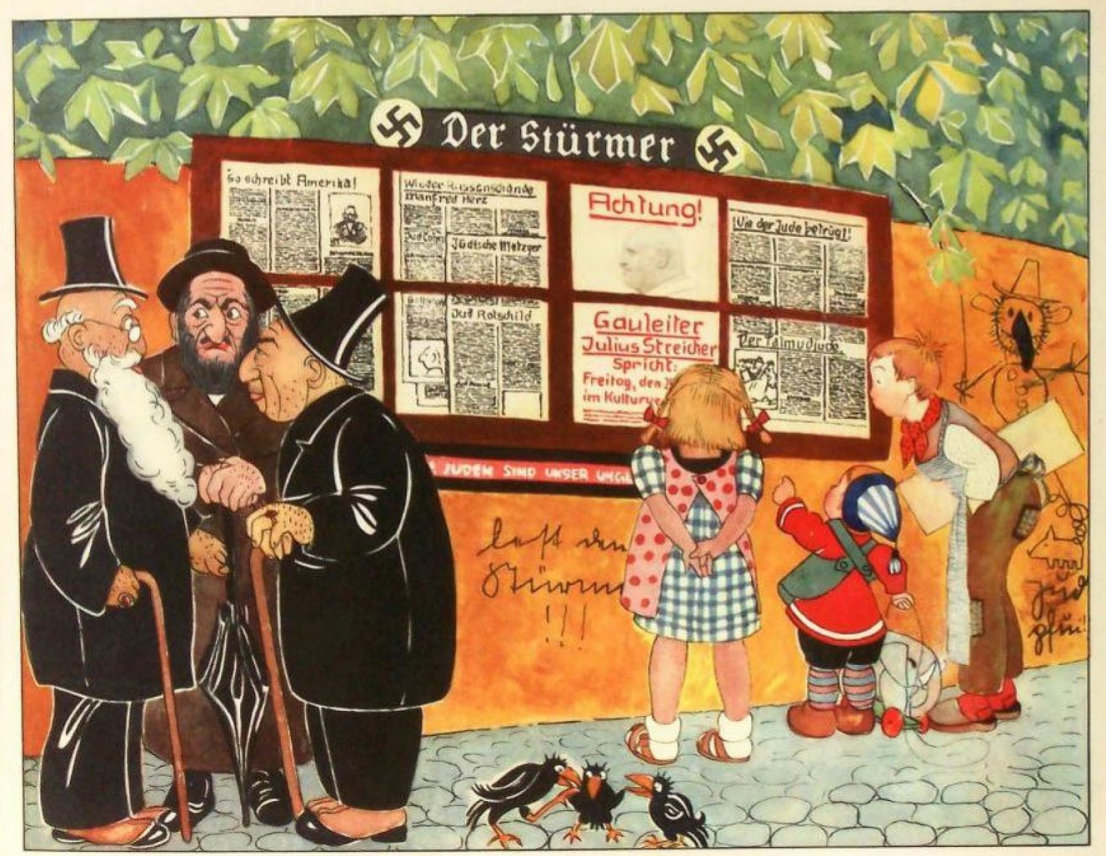

Fig. 6 Illustration from Trust No Fox on his Green Heath And No Jew on his Oath extolling Der Stürmer and its publisher Julius Streicher as trusted sources of anti-Semitic information for children. Internet Archive, Open Source collection (no copyright) https://archive.org/details/ElviraBauerTrauKeinemFuch sAufGruenerHeidUndKeinemJudBeiSeinemEid46S/page/n33/mode/2up

medicine, education, journalism, and literature all attest to Streicher's valor and Jews' perfidy. This confused state of affairs conforms to the ambitious goals of Nazi pedagogy and state policy, which set the context for the propaganda children's texts. Everything is bound up with everything else. Distinctions, diversity, and any trace of disparity between science and story are dismissed.

\section{Conclusion: History as Laboratory}

Casting racist dogma as scientific fact was central to the political philosophy of the Nazi state and its children's propaganda. Biologists and doctors extending to the upper echelons of the German academic community enthusiastically enlisted in the effort to translate science into ideology and vice versa (Hayes and Roth, 2010, p. 4). For example, a 1940 article by prominent Austrian biologist Konrad Lorenz (later 
winner of the 1973 Nobel Prize in Physiology or Medicine) in the official pedagogical journal of the biology wing of the National Socialists Educators' League describes the "racial idea as the basis of our state" (Lerner, 1992, p. 64). Lorenz calls for extreme measures: "Race-care must consider an even more stringent elimination of the ethically less valuable than is done today" (p. 64). This article appeared when the Nazis' T4 mass-murder euthanasia program was at its peak. Nonetheless, Lorenz heartily endorses "the extermination of elements of the population loaded with dregs" (ibid.). Lerner writes, "It is difficult to determine whether this 1940 article is a scientific statement or a Nazi political statement" (p. 62). However, to parse a distinction between science and ideology in Nazi communication misses the larger point: Nazi ideology was inherently scientific in its approach and mythic in its scope. Expressing this elision of any difference between the ideological aims of the state and the findings of scientific biology, one Nazi doctor said, "We wanted to put into effect the laws of life, which are biological laws" (Lifton, p. 31). Those putative laws of life and laws of nature were recruited as rationales for ghastly campaigns of death, first the euthanasia program and later the Final Solution. Nazi leaders claimed they were merely implementing scientific findings while accomplished scientists like Lorenz were corrupted into supporting the regime's policies.

The Nazis assumed that history would eventually confirm their theories of racial biology. Murderous projects of mass euthanasia and then genocide were experiments meant to prove their eugenicist hypotheses. In this regard, the German nation was to be a public laboratory for the regime's ideology and the scientific ideas on which it rested. In Hiemer's and Bauer's books and in pedagogical textbooks of Nazi racial science such as Bareth and Vogel's 1937 Erblehre und Rassenkunde für die Grund- und Hauptschule, German youth were told a tale about an unfolding scientific drama in which they played a key role. Once Nazi education was brought under the aegis of applied biology at the start of the Third Reich in 1933, the entire curriculum was remade not only to uphold the racist tenets of Nazi science, but to be a catalyst in bringing those conditions to life. Histories of Nazi education by Christoph Eppler (2012), Harald Scholtz (2009), and Lisa Pine (2010) concur with Wegner's claim regarding the preeminent place of biology in Nazi pedagogy. A biology teacher speaking at a teachers' convention in the summer of 1933 affirmed the relevance of "racial science" to all parts of the Nazi curriculum: "Teachers, especially those of us in biology, are under the obligation to establish the deep associations between hereditary science, the Völkisch [nationalist] world view and the life of our people" (Wegner, p. 99). A 1933 directive regarding curricular standards similarly mandated that principles of biological racism were to form "the basis for all educational endeavors under the Nazi regime. Biological knowledge and understanding were not to be restricted to the natural sciences but were to permeate all disciplines" (Wegner, p. 99). Education and children's literature under the Nazis did not so much reflect reality as strive to remake it.

The tight curricular integration between science, ideology, and literature in the Third Reich raises questions about how to foster critical engagement with the portrayal of science in works of children's nonfiction. For example, one can already imagine future children's histories of the COVID-19 pandemic and the murky origins of the virus aggravating the anti-Asian racism and broader xenophobia that the 
pandemic engendered. The historical example of Nazi children's literature demonstrates that the myths of nationalist ideology tantalize most when dressed in scientific garb. When bad science becomes the basis for bad children's literature, the results can prove poisonous, even deadly.

Funding This research was supported by The Israel Science Foundation (Grant No. 595/20).

\section{References}

Allchin, Douglas. (2003). Scientific Myth-Conceptions. Science Education, 87(3), 329-351.

Bareth, Karl, and Vogel, Alfred. (1937). Erblehre und Rassenkunde für die Grund- und Hauptschule. Bühl: Konkordia.

Bauer, Elvira. (1936). Trau keinem Fuchs auf grüner Heid und keinem Jud auf seinem Eid. Illustrated by Philipp Rupprecht. Nuremberg: Stürmer-Buchverlag.

Burleigh, Michael, and Wippermann, Wolfgang. (1991). The Racial State: Germany, 1933-1945. Cambridge: Cambridge University Press.

Bytwerk, Randall. (2001). Julius Streicher. New York: Cooper Square Press.

Eppler, Christoph J. (2012). Erziehung im Nationalsozialismus. Beltheim-Schnellbach: Lindenbaum.

Friedländer, Saul. (1997). The Years of Persecution: Nazi Germany and the Jews, 1933-39. New York: Harper Collins.

Friedländer, Saul. (2007). The Years of Extermination: Nazi Germany and the Jews, 1939-1945. New York: Harper Collins.

Giorgi, Marisa. (2012). (Re)Forming Italians: Children's Literature in Italy, 1929-1939. [Doctoral dissertation, City University of New York]. CUNY Academic Works. https://academicworks.cuny.edu.

Hayes, Peter, and Roth, John K. (2010). "Introduction". The Oxford Handbook of Holocaust Studies (pp. 1-20). Oxford: Oxford University Press.

Hiemer, Ernst. (1938). Der Giftpilz. Ill. Philipp Rupprecht. Nuremberg: Stürmer-Buchverlag.

Hiemer, Ernst. (1940). Der Pudelmopsdackelpinscher. Nuremberg: Stürmer-Buchverlag.

Hollander, Amanda. (2017). Liberty in the Age of Eugenics: Non-Normative Bodies in Fabian Socialist Children's Fiction. In Roxanne Harde and Lydia Kokkola (Eds.), The Embodied Child: Readings in Children's Literature and Culture (pp. 127-140). New York: Routledge.

Keely, Karen A. (2004). Teaching Eugenics to Children: Heredity and Reform in Jean Webster's DaddyLong-Legs and Dear Enemy. The Lion and the Unicorn, 28(3), 363-389. https://doi.org/10.1353/ uni.2004.0032.

Lerner, Richard M. (1992). Final Solutions: Biology, Prejudice, and Genocide. University Park: Penn State University Press.

Lifton, Robert Jay. (1986). The Nazi Doctors: Medical Killing and the Psychology of Genocide. New York: Basic Books.

McLean, Eden K. (2018). Mussolini's Children: Race and Elementary Education in Fascist Italy. Lincoln: University of Nebraska Press.

Mickenberg, Julia L. (2005). Learning from the Left: Children's Literature, the Cold War, and Radical Politics in the United States. Oxford: Oxford University Press.

Pauwels, Frauke. (2019). Reading as a Scientist: Children's Nonfiction through a Cognitive Lens. Children's Literature Association Quarterly, 44(4), 432-446.

Pendas, Devin O., et al. (2017). "Introduction." Beyond the Racial State: Rethinking Nazi Germany (pp. 1-28). Cambridge: Cambridge University Press.

Pine, Lisa. (2010). Education in Nazi Germany. Oxford: Berg.

Proud, Judith K. (1998). Occupying the Imagination: Fairy Stories and Propaganda in Vichy France. The Lion and the Unicorn, 22(1), 18-43. https://doi.org/10.1353/uni.1998.0012.

Reynolds, Kimberley. (2016). Left Out: The Forgotten Tradition of Radical Publishing for Children in Britain 1910-1949. Oxford: Oxford University Press. 
Sanders, Joe Sutliff. (2018). A Literature of Questions: Nonfiction for the Critical Child. Minneapolis: University of Minnesota Press.

Scholtz, Harald. (2009). Erziehung und Unterricht unterm Hakenkreuz. Göttingen: Vandenhoeck \& Ruprecht.

Seitler, Dana. (2003). Unnatural Selection: Mothers, Eugenic Feminism, and Charlotte Perkins Gilman's Regeneration Narratives. American Quarterly, 55(1), 61-88. https://doi.org/10.1353/aq.2003.0001.

Stanley, Jason. (2015). How Propaganda Works. Princeton: Princeton University Press.

Stone, Dan. (2017). Race Science, Race Mysticism, and the Racial State. In Devin O. Pendas, et al. (Eds.), Beyond the Racial State: Rethinking Nazi Germany (pp. 176-196). Cambridge: Cambridge University Press.

Straley, Jessica. (2016). Evolution and Imagination in Victorian Children's Literature. Cambridge: Cambridge University Press.

Vogel, Alred. (1938). Erblehre und Rassenkunde in bildlicher Darstellung. Stuttgart: Verlag für nationale Literatur.

Webster, Jean. (1915). Dear Enemy. New York: Century.

Wegner, Gregory Paul. (2002). Anti-Semitism and Schooling Under the Third Reich. New York: Routledge.

Wetzell, Richard F. (2017). Eugenics, Racial Science, and Nazi Biopolitics: Was There a Genesis of the "Final Solution" from the Spirit of Science? In Devin O. Pendas, et al. (Eds.), Beyond the Racial State: Rethinking Nazi Germany (pp. 147-175). Cambridge: Cambridge University Press.

Zarnowski, Myra, and Turkel, Susan. (2013). How Nonfiction Reveals the Nature of Science. Children's Literature in Education, 44, 295-310.

Publisher's Note Springer Nature remains neutral with regard to jurisdictional claims in published maps and institutional affiliations. 